\section{Galileo's send-off}

\section{An upcoming mission to Jupiter should include a piece of the famous astronomer.}

A t an aerospace facility in Denver, Colorado, engineers are busy attaching scientific instruments to NASA's next mission to Jupiter, which is set for launch in less than a year. But team members on the billion-dollar Juno mission are quietly talking about slipping something extra onto the spacecraft - a tiny fragment of bone from Galileo Galilei.

The idea of sending a piece of the famed astronomer to orbit the giant planet, in the company of the moons that he discovered, has charmed some of the US participants in the mission. Officials at the Italian Space Agency, which is providing two instruments, seem to be less enthusiastic. But the plan should move forward.

The wariness on the Italian side is understandable. Galileo died in 1642 , still under house arrest for his heretical views, and his burial place lay hidden until 1737, when civil authorities moved him to a prominent spot in the Basilica of Santa Croce in Florence, Italy. Since then, the Franciscan order that runs the church has done its best to protect his remains. A 2008 proposal to exhume the body for genetic tests met with fierce opposition from the church's rector, who described such high-profile scientific efforts as resembling "a carnival".

Yet Galileo has never been wholly at rest. During the reburial,

attending naturalist Giovanni Targioni Tozzetti pried off the thumb and forefinger of Galileo's right hand for posterity; earlier this year, the bones went on display at a museum a few blocks from Santa Croce. And one of the astronomer's vertebrae is held by the University of

"A sliver of bone seems a modest sacrifice for a gesture that would remind the public that science is a human endeavour."
Padua, where he once taught.

Compared with these disruptions of Galileo's eternal slumber, a sliver of bone seems a modest sacrifice for a gesture that would add emotional energy to the mission and remind the public that science is fundamentally a human endeavour.

Galileo himself understood the need to connect science with society, and he was politically astute enough to see the value of showmanship. It was no coincidence that he named the four biggest moons of Jupiter the 'Medicean stars' after his patrons, and accompanied his announcement of their discovery with a gift of an almost priceless telescope to Cosimo II de' Medici, the Grand Duke of Tuscany. Galileo might have tolerated a little post-mortem exploitation in the interests of public support.

But there is another reason to think that Galileo would have approved. He was enthralled by the Universe revealed through his telescope. "It is a very beautiful thing, and most gratifying to the sight, to behold the body of the moon, distant from us almost sixty earthly radii, as if it were no farther away than two such measures," he wrote of the lunar surface in his 1610 treatise The Starry Messenger. The Juno mission will skim just 4,800 kilometres above Jupiter, a body that held no less fascination for Galileo. He just might enjoy a closer look. .

\section{A painful remedy}

The number of papers being retracted is on the rise, for reasons that are not all bad.

$\mathrm{F}$ ew experiences can be more painful to a researcher than having to retract a research paper. Some papers die quietly, such as when other scientists find that the work cannot be replicated and simply ignore it. Yet, as highlighted by several episodes in recent years, the most excruciating revelation must be to find not only that a paper is wrong, but that it is the result of fraud or fabrication, which itself requires months or years of investigation. Where once the research seemed something to be exceptionally proud of, the damage caused by fraudulent work can spread much wider, as discovered by associates of the Austrian physicist Jan Hendrick Schön and the South Korean stem-cell biologist Woo Suk Hwang. But whatever the reason for a retraction, all of the parties involved - journals included - need to face up to it promptly.

This year, Nature has published four retractions, an unusually large number. In 2009 we published one. Throughout the past decade, we have averaged about two per year, compared with about one per year in the 1990s, excluding the pulse of retractions of papers co-authored by Schön.

Given that Nature publishes about 800 papers a year, the total is not particularly alarming, especially because only some of the retractions are due to proven misconduct. A few of the Nature research journals have also had to retract papers in recent years, but the combined data do no more than hint at a trend. A broader survey revealed even smaller proportions: in 2009, Times Higher Education commissioned a survey by Thomson Reuters that counted 95 retractions among 1.4 million papers published in 2008. But the same survey showed that, since 1990 during which time the number of published papers doubled - the proportion of retractions increased tenfold (see go.nature.com/vphd17).

So why the increase? More awareness of misconduct by journals and the community, an increased ability to create and to detect unduly manipulated images, and greater willingness by journals to publish retractions must account for some of this rise. One can also speculate about the increasing difficulty for senior researchers of keeping track of the detail of what is happening in their labs. This is of concern not just because of the rare instances of misconduct, but also because of the risk of sloppiness and of errors not being caught. Any lab with more than ten researchers may need to take special measures if a principal investigator is to be able to assure the quality of junior members' work.

The need for quality assurance and the difficulties of doing it are exacerbated when new techniques are rapidly taken up within what is often a highly competitive community. And past episodes have shown the risk that collaborating scientists - especially those who are geographically distant - may fail to check data from other labs for which, as co-authors, they are ultimately responsible.

If we at Nature are alerted to possibly false results by somebody who was not an author of the original paper, we will investigate. This is true even if the allegations are anonymous - some important retractions in the literature have arisen from anonymous whistle-blowing. However, we are well aware of the great damage that can be done to co-authors as a result of such allegations, especially when the claims turn out to be false. Such was the case with a recent e-mail alert widely distributed by a group calling itself Stem Cell Watch (see Nature 467, $1020 ; 2010)$ - an action that we deplore.

For our part, we are sensitive to such concerns and will bear in mind the need to protect the interests of authors until our obligation to the community at large becomes clear. But then we will publish a retraction promptly, and link to it prominently from the original papers. We will also list the retraction on our press release if the original paper was itself highlighted to the media.

Ultimately, it comes down to the researchers - those most affected $\rightarrow$ NATURE.COM To comment online, click on Editorials at: go.nature.com/xhunqv by the acts - to remain observant and diligent in pursuing their concerns wherever they lead, and where necessary, to correct the literature promptly. Too often, such conscientious behaviour is not rewarded as it should be. 